\title{
Synergistic effects of plant defense elicitors and Trichoderma harzianum on enhanced induction of antioxidant defense system in tomato against Fusarium wilt disease
}

\author{
Andleeb Zehra ${ }^{1,2^{*}}$, Mukesh Meena ${ }^{1}$, Manish Kumar Dubey ${ }^{1}$, Mohd. Aamir $^{1}$ and R. S. Upadhyay ${ }^{1}$
}

\begin{abstract}
Plant defense against their pathogens can be induced by a complex network of different inducers. The present study investigates the synergistic effect of Trichoderma harzianum, exogenous salicylic acid (SA) and methyl jasmonate (MeJA) over the response and regulation of the antioxidant defense mechanisms and lipid peroxidation in tomato plants against Fusarium wilt disease. In the present work, tomato plants were infected by Fusarium oxysporum f. sp. lycopersici 3 days after inoculated with T. harzianum and/or sprayed daily for 3 days with chemical inducers (SA and MeJA). Plants were analysed at 0, 24, 48, 72 and $96 \mathrm{~h}$ after inoculation with Fusarium oxysporum f. sp. Iycopersici. Infection of tomato plants by pathogen led to strong reduction in the dry weight of roots and shoots with the enhanced concentration of $\mathrm{H}_{2} \mathrm{O}_{2}$ and varying degree of lipid peroxidation. Concurrently, exogenous $\mathrm{SA}$, when applied with pathogen greatly enhanced $\mathrm{H}_{2} \mathrm{O}_{2}$ content as well as activities of antioxidant enzymes except catalase (CAT) and ascorbate peroxidase (APX). The pathogen challenged plants pretreated with T. harzianum and MeJA together exhibited less lipid peroxidation and as well as the elevated level of ascorbic acid and enhanced activities of antioxidant enzymes. All applied treatments protected tomato seedlings against Fusarium wilt disease but the percentage of protection was found higher in plants pretreated with the combination of T. harzianum and chemical inducers.
\end{abstract}

Keywords: Trichoderma harzianum, Chemical inducers, Reactive oxygen species, Antioxidant system, Lipid peroxidation

\section{Introduction}

Tomato (Lycopersicon esculentum Mill.) is a major contributor to the fruits and vegetable diet of humans throughout the world (Kapsiya et al. 2015). However, its growth, yield and economic productivity are significantly reduced by several pathogens. Fusarium wilt disease of tomato caused by Fusarium oxysporum f. sp. lycopersici is one of the most devastating disease worldwide which causes yield reduction and affects tomato production (Hanaa et al. 2011). The fungal pathogen resides in the soil and causes infection to susceptible tomato plants by the roots throughout their course of development

\footnotetext{
*Correspondence: zandleeb142@gmail.com

2 Department of Botany, Banaras Hindu University, Varanasi 221 005, India Full list of author information is available at the end of the article
}

causing necrosis and inducing wilting of the plants at the later stages of their infection and reduces the yield and hence limits the overall economic productivity (El-khallal 2007a, b).

Many biotic and abiotic agents can effectively induce plant resistance against various pathogens (Ramamoorthy et al. 2001; Edreva 2004). Bio-agents can induce resistance against various diseases caused by many pathogens such as viruses (Maurhofer et al. 1994), bacteria (Park and Kloepper 2000) and fungi (Bokhari and Perveen 2012). In spite of these, some bioagents such as Trichoderma spp. have been reported to promote plant growth, nutrient uptake, and induction of plant defense responses against different biotic and abiotic stresses (Harman et al. 2004; Shoresh et al. 2010; Hermosa et al. 2012). There are several evidences which support that 
Trichoderma spp. are able to induce the defense mechanisms in several plants (Vinale et al. 2008; Brotman et al. 2012). The results obtained through $2 \mathrm{D}$ electrophoresis and high-density oligonucleotide microarrays confirmed the induction of proteome and differential gene expression in plant system when inoculated with Trichoderma spp. (Marra et al. 2006; Alfano et al. 2007; Segarra et al. 2007). Different chemical inducers such as salicylic acid (SA), jasmonic acid (JA) and methyl jasmonate (MeJA) are signal molecules that play a key role in plant growth and development, and in the induction of plant defense responses to various abiotic and biotic stress factors (Sticher et al. 1997; War et al. 2011a, b). Various physiological, biochemical and molecular processes in plants including antioxidative enzyme activities can be manipulated by exogenous application of SA and JA (Idrees et al. 2011; War et al. 2011a, b). SA and MeJA play a role in various signal transduction mechanisms associated with plant defense and also elicit the expression of various important enzymes catalyzing a wide array of biosynthetic reactions whose products, through a complex network results in formation of various types of defense compounds including polyphenols, alkaloids and pathogenesis-related (PR) proteins (Hahlbrock and Scheel 1989; Creelman and Mullet 1995), conferring plant protection from pathogen-attack (Delaney et al. 1994; Kozlowski et al. 1999). The transcriptional reprogramming associated with plant defense responses are mediated by SA against different biotic and abiotic stresses (Herrera-Vásquez et al. 2015). Both endogenous and exogenous SA was evidenced to play roles in antioxidant metabolism and have a tight control over cellular ROS (Kang et al. 2014). In the current scenario, the plant protection provided by induction of systemic resistance is an effective and simple approach to disease management. The resistance of plants to pathogens can be enhanced by the application of various biotic and abiotic agents. However, combining different biocontrol agents with chemical inducers can significantly enhance the resistance of a plant and contribute to better control of pathogens (Elkhallal 2007a, b).

Plants have developed effective defense mechanisms to survive after pathogen attack. The generation of reactive oxygen species (ROS) including superoxide anions $\left(\mathrm{O}_{2}^{-}\right)$, hydroxyl radicals $\left(\mathrm{OH}^{-}\right)$and hydrogen peroxide $\left(\mathrm{H}_{2} \mathrm{O}_{2}\right)$ is the principal indication of early plant defense response encountered with the pathogen and recognized by the same (Torres et al. 2006; Lehmann et al. 2015). One of the key functions associated with ROS system is the regulation of several biological and physiological processes including growth and development of plants and mitigation of both biotic and/or abiotic stresses by acting as a key signaling intermediates (Mittler et al. 2011;
Baxter et al. 2013). Moreover, these ROS intermediates have been found to be implicated in defense response of plant through a plethora of mechanistic actions which is exemplified by cross-linking reactions of lignin and proteins causing plant cell-wall reinforcement, exposure of hypersensitive response (HR), or development of SAR against the targeted pathogen and least by acting as toxic agents against either the host plant cells, or the with development of SAR, or against the pathogen through killing them or ceasing their microbial activity. These ROS molecules have also been implicated in defense signaling pathway by acting as secondary messengers in signaling mechanism leading into the expression and activation of plant defense-related genes (Shimizu et al. 2006). Fortunately, plants possess effective mechanisms for detoxification of ROS in order to protect themselves from the toxic effects. Induction of antioxidant enzymes is a major defense mechanism of plants. Different antioxidant enzymes such as superoxide dismutase (SOD), catalase (CAT), ascorbate peroxidase (APx) and guaiacol peroxidase (GPx) involved in ROS metabolism during pathogen infection. SOD catalyses the dismutation reaction of $\mathrm{O}_{2}^{-}$radicals to $\mathrm{O}_{2}$ and $\mathrm{H}_{2} \mathrm{O}_{2} \cdot \mathrm{H}_{2} \mathrm{O}_{2}$ is rapidly removed by CAT and peroxidases. CAT effectively eliminates the most of the $\mathrm{H}_{2} \mathrm{O}_{2}$, whereas APx can scavenge $\mathrm{H}_{2} \mathrm{O}_{2}$ that is inaccessible for CAT because of their higher affinity towards $\mathrm{H}_{2} \mathrm{O}_{2}$ and their occurrence in distinctive sub cellular locations (Creissen et al. 1994; Scandalios et al. 1997).

Here, the objective of this study was to find out the integrated effect of the biocontrol agent, T. harzianum and chemical inducers, SA and MeJA on biochemical changes in tomato plants against Fusarium oxysporum $\mathrm{f}$. sp. lycopersici which leads to elicitation of plant defense response.

\section{Materials and methods Isolation and identification of pathogen}

Fusarium oxysporum f. sp. lycopersici (Fol) was isolated from diseased tomato plants showing typical wilt symptoms on potato dextrose agar (PDA) media and incubated at $25-27{ }^{\circ} \mathrm{C}$ for $5-7$ days. Stock cultures of Fol were prepared and stored at $4{ }^{\circ} \mathrm{C}$. Pathogenicity test for all the isolates of Fol was done by following Koch's postulate. A highly virulent isolate was selected for further experiments.

\section{Collection of Trichoderma species}

Trichoderma harzianum BHU BOT RYRL4 (NCBI Accession No-KR 856210) and T. asperellum BHU BOT RYRL1 (NCBI Accession No-KR 856207) were provided from RY Roy Laboratory of Mycopathology, Department of Botany, Banaras Hindu University, Varanasi, India. 
T. harzianum MTCC 936, T. viride MTCC 793 and T. asperellum MTCC 4347 were procured from Microbial Type Culture Collection (MTCC), IMTECH, Chandigarh, India. Some spp. of Trichoderma was also isolated from soil samples of the rhizospheric soil of tomato plants from different places of India. All the fungal cultures were maintained in tubes of Potato Dextrose Agar (PDA) slant medium supplemented with streptomycin antibiotic and stored at $4{ }^{\circ} \mathrm{C}$ for 6 months and revived thereafter.

\section{Evaluation of the antagonistic activity of Trichoderma spp.} Different strains of Trichoderma spp. were screened for the evaluation of antagonistic activity against the pathogen by inoculating a $5 \mathrm{~mm}$ mycelial plug in the Petri plates. In the same Petri dishes perpendicular to the Trichoderma fungal disc, a $5 \mathrm{~mm}$ mycelial disc of 5 -day-old pathogen culture was placed $6 \mathrm{~cm}$ away at the opposite side of the Petri dish. Plates were incubated at $27 \pm 2{ }^{\circ} \mathrm{C}$ and growth of the pathogen mycelia towards the fungal disc was observed, and percent inhibition were measured 5 days after incubation. Data were obtained for the percentage inhibition of radial growth $[100 \times(C-T) / C]$ where $C=$ radial growth of the pathogen in control and $\mathrm{T}=$ radial growth of the pathogen in dual culture with antagonist (Garrett 1956). The experiment was repeated thrice.

\section{Inoculum preparation}

For the preparation of the inoculum, spore suspensions from 7 days old cultures of Trichoderma spp. were flooded and mixed with glass rod using sterilized distilled water. The suspension was then filtered through cheese cloth and further diluted with distilled water to obtain a final concentration of $1 \times 10^{5}$ spores $/ \mathrm{ml}$ using haemocytometer. Similarly, the inoculum preparation for pathogen was also done and the final concentration was maintained to $2 \times 10^{5}$ spores $/ \mathrm{ml}$.

\section{Plant material and growth}

Tomato (Lycopersicon esculentum cv. Punjab chhuara) seeds were obtained from Indian Institute of Vegetable Research (Adalpura, Varanasi) and were surface-sterilized in $0.5 \%$ sodium hypochlorite solution for $20 \mathrm{~min}$ and grown in autoclaved soil in greenhouse under alternate $14 \mathrm{~h}$ light and $10 \mathrm{~h}$ dark cycle at 27 and $22{ }^{\circ} \mathrm{C}$, respectively. After attaining a height of $15-20 \mathrm{~cm}$, these plants were used for testing pathogenicity against pathogen and also for further experiments.

\section{Pathogenicity test}

Pathogenicity test was carried out by inoculating healthy $15-20 \mathrm{~cm}$ tall plants with the spore suspension of pathogen containing $2 \times 10^{5}$ spores $/ \mathrm{ml}$ followed by $48 \mathrm{~h}$ of incubation in the moist chamber after which the plants were returned to the green house chamber. Greenhouse temperature ranged from 25 to $29^{\circ} \mathrm{C}$ with alternate $14 \mathrm{~h}$ light and $10 \mathrm{~h}$ dark cycles.

\section{Evaluation of tomato plant growth characteristics of different Trichoderma strains}

An in vivo assay was used to evaluate the abilities of different Trichoderma strains to promote tomato plant growth. Tomato seeds were coated with an aqueous suspension containing $1 \times 10^{5}$ spores of Trichoderma per $\mathrm{ml}$ ( $1 \mathrm{ml}$ of spore suspension/30 seeds) and then air dried in an open petri-dish overnight under a laminar flow hood. Treated tomato seeds were sown in pots containing soil autoclaved at $121{ }^{\circ} \mathrm{C}$ for $1 \mathrm{~h}$ on 2 successive days. Pots with untreated tomato seeds were used as controls. The pots were incubated in a greenhouse at temperature ranged from 25 to $29{ }^{\circ} \mathrm{C}$ and watered as needed. Measurements of shoot length, stem diameter, and main root length were taken after 4 weeks.

\section{In vitro antifungal activity assay of SA and MeJA against $F$. oxysporum f. sp. lycopersici and Trichoderma species}

The effect of SA and MeJA was tested on radial growth of Fol and different strains of Trichoderma spp. cultured on potato dextrose agar (PDA) medium. The PDA was amended with SA and MeJA at 50, 100, 150, 200, 250 and $300 \mu \mathrm{M}$ concentrations. Diameters of the fungal colony were measured at 7 days after inoculation with a $5 \mathrm{~mm}$ diameter plug of Fol and Trichoderma species.

\section{Phytotoxic assay of SA and MeJA against tomato plants}

The tomato plants were sprayed with $50,100,150,200$, 250 and $300 \mu \mathrm{M}$ concentrations of SA and MeJA to detect the phytotoxicity of these elicitors against tomato plants. After 7 days, the plants were assayed for their phytotoxicity.

\section{Treatment of plant material}

When the tomato seedlings were 3-4 weeks old and $15-20 \mathrm{~cm}$ tall, tomato seedlings were inoculated with T. harzianum at $1 \times 10^{5}$ spores $/ \mathrm{ml}$ and/or sprayed daily with chemical inducers, SA and MeJA $(200 \mu \mathrm{M})$ on the leaf surface every $24 \mathrm{~h}$ for 3 consecutive days. Then, plants were inoculated with the spore suspension of Fol $\left(2 \times 10^{5}\right.$ spores $\left./ \mathrm{ml}\right)$.

\section{Plant harvest and analysis}

The plants were harvested and the leaves from treated and control plants at five different stages at $0,24,48$, 72 and $96 \mathrm{~h}$ post inoculation with pathogen, were collected for the assessment of active concentration of 
$\mathrm{H}_{2} \mathrm{O}_{2}$, ascorbic acid, malondialdehyde (MDA). The enzymatic activities of different antioxidative enzymes including (SOD, APx, GPx and CAT) were also determined. In addition, we have also analyzed the effect of all the treatments given over the dry weight of roots and shoots. The treatments given were provided in the following combinations, Fusarium oxysporum f. sp. lycopersici $+\mathrm{SA}+$ Trichoderma harzianum, $F$. oxysporum f. $\mathrm{sp}$. lycopersici $+\mathrm{MeJA}+T$. harzianum, $F$. oxysporum f. sp. lycopersici + SA, F. oxysporum f. sp. lycopersici + MeJA, F. oxysporum f. sp. lycopersici + T. harzianum, F. oxysporum f. sp. lycopersici challenged and healthy control. For each treatment, three replicates having five seedlings per replicate were maintained.

\section{3,3'-Diaminobenzidine (DAB) staining to detect $\mathrm{H}_{2} \mathrm{O}_{2}$ accumulation}

Histochemical detection of $\mathrm{H}_{2} \mathrm{O}_{2}$ was done by 3,3'-diaminobenzidine (DAB) staining as described by ThordalChristensen et al. (1997). Leaves of control and treated plants were cut with the razor blade and were immediately placed in a beaker containing $1 \mathrm{mg} / \mathrm{ml} 3,3^{\prime}$-diaminobenzidine-hydrochloric acid (DAB-HCL), adjusted to $\mathrm{pH} 5.6$ with $\mathrm{NaOH}$, and were incubated in a growth chamber for $8 \mathrm{~h}$ in the dark. This was followed by further washing and destaining in $96 \%$ boiling ethanol. Microscopic observation was made to find out the location of cells with $\mathrm{H}_{2} \mathrm{O}_{2}$ accumulation. The red-brown coloration was observed in the sample that shows the sites of $\mathrm{H}_{2} \mathrm{O}_{2}$ deposition.

\section{$\mathrm{H}_{2} \mathrm{O}_{2}$ estimation}

The $\mathrm{H}_{2} \mathrm{O}_{2}$ produced was determined as described by Sagisaka (1976). Leaf tissues from control and treated plants were homogenised in 5\% cold trichloro acetic acid (TCA) and the homogenate was centrifuged at $17,000 \mathrm{~g}$ for $10 \mathrm{~min}$ at $0{ }^{\circ} \mathrm{C}$. The reaction mixture consisted of $1.6 \mathrm{ml}$ of supernatant, $0.4 \mathrm{ml}$ of $50 \% \mathrm{TCA}, 0.4 \mathrm{ml}$ of ferrous ammonium sulphate and $0.2 \mathrm{ml}$ of potassium thiocyanate. The amount of $\mathrm{H}_{2} \mathrm{O}_{2}$ was measured by a calibration curve prepared with known concentrations of $\mathrm{H}_{2} \mathrm{O}_{2}$ by measuring the absorbance at $480 \mathrm{~nm}$ after $15 \mathrm{~min}$ of incubation.

\section{Measurement of cell death}

Histochemical analysis was done to check the degree of cell death using Evans blue staining. For this, the control and treated leaves were boiled for $1 \mathrm{~min}$ in a freshly prepared solution of phenol, lactic acid, glycerol and distilled water (1:1:1:1) containing $20 \mathrm{mg} / \mathrm{ml}$ Evans blue. The tissues after boiling were cleared overnight in a solution of $2.5 \mathrm{~g} / \mathrm{ml}$ chloral hydrate in water. This staining easily demarcates the dead cells having intense blue stain as compared to the control plants that remained unstained.
The extent of cell death was measured by the method by Baker and Mock (1994). In this method, the samples from both control and treated leaf tissues were treated separately with $1 \mathrm{ml} 0.25 \%$ solution of Evans blue and the samples were further incubated on a platform shaker at $27{ }^{\circ} \mathrm{C}$ and $80 \mathrm{rpm}$ for $20 \mathrm{~min}$. The samples were washed with deionized water in order to remove the traces of the dye from leaf tissues. For the removal of tissues bound dye, the samples were transferred to a $1.5 \mu$ centrifuge tube and treated with $1.5 \%$ aqueous sodium dodecyl sulphate (SDS). The samples were crushed with mortar and pestle and the homogenates thus obtained were then diluted with $0.5 \%$ deionized water and were vortexed for $30 \mathrm{~s}$. The samples were further transferred to the fresh tubes and centrifuged at $9000 \mathrm{~g}$ for $3 \mathrm{~min}$. The supernatant was taken in $0.8 \mathrm{ml}$ aliquot and optical density was measured spectrophotometrically at $600 \mathrm{~nm}$.

\section{Ascorbic acid (AsA) content}

Ascorbic acid was estimated by the method described by Keller and Schwager (1977). $0.1 \mathrm{~g}$ of fresh leaves from each of the treatments were homogenised with $2.0 \mathrm{ml}$ of extracting solution ( $5 \mathrm{~g}$ oxalic acid $+0.75 \mathrm{~g}$ EDTA in $1000 \mathrm{ml}$ of distilled water), centrifuged at $10,000 \mathrm{~g}$ for $10 \mathrm{~min}$ and the supernatant was collected. To $1 \mathrm{ml}$ of supernatant, $5 \mathrm{ml}$ of $20 \mu \mathrm{g} / \mathrm{ml}$ of 2,6-dichlorophenolindophenol (DCPIP) dye was added to develop color. The absorbance of the mixture was noted at $520 \mathrm{~nm}$ against the blank. The standard curve was prepared by using the different concentration of ascorbic acid by following the same method. The concentration of ascorbic acid is calculated by using the method of Keller and Schwager (1977).

\section{Lipid peroxidation (LPO)}

The extent of LPO was determined by using the method as described by Ohkawa et al. (1979). Estimation of total malondialdehyde (MDA), content produced as a secondary byproduct of polyunsaturated fatty acid peroxidation by the thiobarbituric acid (TBA) reaction is a major determinant of the extent of LPO content. The leaf samples from each of the treatments were homogenized in a buffer, centrifuged and the supernatant was used as extract for the assay. The reaction mixture consisted of $0.1 \mathrm{ml}$ of extract, $0.2 \mathrm{ml}$ of $8.1 \%$ SDS, $1.5 \mathrm{ml}$ of $20 \%$ acetic acid and $1.5 \mathrm{ml}$ of $0.8 \%$ aqueous solution of TBA. The volume of the reaction mixture was maintained up to $4.0 \mathrm{ml}$ with distilled water and incubated at $95{ }^{\circ} \mathrm{C}$ for $1 \mathrm{~h}$ in water bath. After cooling, $1.0 \mathrm{ml}$ of distilled water and $5.0 \mathrm{ml}$ of mixture of $n$-butanol and pyridine (15:1 by vol) was added and centrifuged at 10,000 $g$ for $15 \mathrm{~min}$. The spectrophotometric absorbance was measured at $532 \mathrm{~nm}$ and the amount of MDA was calculated based on an 
extinction coefficient of $155 \mathrm{mM}^{-1} \mathrm{~cm}^{-1}$ and expressed as nmol MDA g ${ }^{-1} \mathrm{FW}$.

\section{Antioxidant enzyme assay \\ Superoxide dismutase (SOD) activity}

SOD (EC 1.15.1.1) activity was determined using a method described by Fridovich (1974). Leaf samples $(0.1 \mathrm{~g})$ from control and treated plants were homogenised in $2.0 \mathrm{ml}$ of extraction buffer $(0.1 \mathrm{M}$ phosphate buffer containing $0.5 \mathrm{mM}$ EDTA at $\mathrm{pH} 7.5$ ) and centrifuged at $12,000 \mathrm{~g}$ for $15 \mathrm{~min}$ at $4{ }^{\circ} \mathrm{C}$. The supernatants thus obtained were used as enzyme extract. The reaction mixture consisted of $200 \mathrm{mM}$ methionine, $2.25 \mathrm{mM} \mathrm{NBT}$, $3 \mathrm{mM}$ EDTA, $100 \mathrm{mM}$ phosphate buffer (pH 7.8), 1.5 M sodium carbonate and enzyme extract. The final volume of the reaction mixture was maintained up to $3 \mathrm{ml}$. The reaction was initiated by adding $400 \mu \mathrm{l}$ of riboflavin $(2 \mu \mathrm{M})$ and the tubes were illuminated for $15 \mathrm{~min}$. The reaction was stopped by keeping the tubes in dark. The absorbance was measured at $560 \mathrm{~nm}$ by measuring the ability of enzyme extract to inhibit photochemical reduction of nitroblue tetrazolium (NBT) chloride.

\section{Ascorbate peroxidase (APx) activity}

APx (E.C. 1.11.1.11) activity was estimated according to the method given by Nakano and Asada (1981) by measuring the oxidation of ascorbic acid at $290 \mathrm{~nm}$ with slight modifications. About $0.1 \mathrm{~g}$ leaf tissue were homogenised in $2 \mathrm{ml}$ of extraction buffer $\left(90 \mathrm{mM} \mathrm{Na}_{2} \mathrm{HPO}_{4}\right.$ buffer, at $\mathrm{pH} 7.8,8 \%$ glycerol, $1 \mathrm{mM}$ EDTA, and $5 \mathrm{mM}$ ascorbate). PVP (0.3 g/g tissue) was added and the homogenate was centrifuged at $15,000 \mathrm{~g}$ for $10 \mathrm{~min}$ at $4{ }^{\circ} \mathrm{C}$. The resulting supernatants were used for the enzymatic assay. Enzyme extract $(200 \mu \mathrm{l})$ was added to the reaction mixture of $25 \mathrm{mM}$ phosphate buffer (pH 7.0), $0.1 \mathrm{mM}$ EDTA, $0.25 \mathrm{mM}$ ascorbic acid and $1.0 \mathrm{mM} \mathrm{H}_{2} \mathrm{O}_{2}$ and the decrease in absorbance was recorded $30 \mathrm{~s}$ after addition of the enzyme extract. APx activity was calculated based on an extinction coefficient $2.8 \mathrm{mM}^{-1} \mathrm{~cm}^{-1}$ and the enzymatic activity was expressed as nmol ascorbate oxidized $\mathrm{min}^{-1} \mathrm{mg}^{-1}$ protein.

\section{Catalase (CAT) activity}

CAT (EC 1.11.1.6) activity was determined by using the method described by Aebi (1984). Plant tissue (0.1 g) from control and treated plants were homogenised in $50 \mathrm{mM}$ Tris $\mathrm{HCl}$ buffer ( $\mathrm{pH} 8.0$ ) containing $0.5 \mathrm{mM}$ EDTA, $2 \% \mathrm{w} / \mathrm{v}$ polyvinylpyrrolidone, and $0.5 \%(\mathrm{v} / \mathrm{v})$ Triton X100. The homogenate was centrifuged at $12,000 \mathrm{~g}$ for $15 \mathrm{~min}$ at $4{ }^{\circ} \mathrm{C}$, and the resulting supernatant was used as enzyme extract. The reaction mixture consisted of $300 \mu \mathrm{M}$ phosphate buffer ( $\mathrm{pH}$ 7.2) and $100 \mu \mathrm{M} \mathrm{H}_{2} \mathrm{O}_{2}$ in $1 \mathrm{ml}$ enzyme extract. Activity was determined by recording $\mathrm{O}_{2}$ released from enzymatic dissociation of $\mathrm{H}_{2} \mathrm{O}_{2}$ in darkness for $1 \mathrm{~min}$. $\mathrm{O}_{2}$ produced by the enzymatic reaction was estimated by measuring the decrease in $\mathrm{H}_{2} \mathrm{O}_{2}$ absorption at $240 \mathrm{~nm}$ (extinction coefficient of $\mathrm{H}_{2} \mathrm{O}_{2}$ is $0.036 \mathrm{mM}^{-1} \mathrm{~cm}^{-1}$ ) and enzyme activity was expressed as $\mu \mathrm{M} \mathrm{H}_{2} \mathrm{O}_{2}$ oxidized min $^{-1} \mathrm{~g}^{-1} \mathrm{FW}$.

\section{Guaiacol peroxidase (GPx) activity}

GPx (EC 1.11.1.7) activity was spectrophotometrically determined as described by Zheng and Van Huystee (1992). The oxidation of guaiacol to tetra guaiacol was estimated by the increase in absorbance at $470 \mathrm{~nm}$ in a reaction mixture that contained $10 \mathrm{mM}$ sodium phosphate $(\mathrm{pH} 6.0), 0.3 \%(\mathrm{v} / \mathrm{v}) \mathrm{H}_{2} \mathrm{O}_{2}, 1 \%(\mathrm{v} / \mathrm{v})$ tetraguaiacol, and $0.3 \mathrm{ml}$ enzyme extract. The reaction was started by the addition of $\mathrm{H}_{2} \mathrm{O}_{2}$. The enzymatic activity was determined in terms of $\mathrm{U} / \mathrm{mg}$ protein as can be extrapolated by the linear portion of the activity curve whose absorbance was measured at $470 \mathrm{~nm}$. The amount of the enzyme catalysing the oxidation of $1 \mu \mathrm{mol}$ of guaiacol $\min ^{1}$ represents one unit of enzyme activity. Protein was estimated following the method of Lowry and others (1951).

\section{Statistical analysis}

All statistical analysis was done by using SPSS ver. 16 . The results are the mean of the three replicates of each of the experiment. The data were statistically analysed by using one-way analysis of variance (ANOVA) and mean separations were compared with Duncan's multiple range tests at the $\mathrm{p} \leq 0.05$ significance level. Differences at $\mathrm{p} \leq 0.05$ were considered to be significant.

\section{Results}

Analysis of the antagonistic activity of Trichoderma species against Fol

Among the different species of Trichoderma, T. harzianum BHU-BOT-RYRL4 showed the highest percentage of inhibition of pathogen growth (83.17\%). Whereas, $T$. asperellum BHU-BOT-RYRL1 showed the lowest inhibition (39.98\%). T. harzianum MTCC 936, T. viride MTCC 793 and T. asperellum MTCC 4347 inhibited the growth of pathogen by $72.13,68.12$ and $50.27 \%$, respectively.

\section{Effect of the different Trichoderma strains on the growth characteristics of tomato plants}

All the tested strains of Trichoderma had a significant effect on the shoot length, root length and stem diameter of tomato plants in comparison to control (Table 1). However, among the different strains of Trichoderma, T. harzianum BHU BOT RYRL 4 showed the highest tomato plant growth characteristics viz. shoot length (147.89\%) root length (192.09\%) and stem diameter (147.5\%) followed by T. harzianum MTCC 936 (shoot 
Table 1 Effect of the different strains of Trichoderma on the plant growth characteristics of tomato

\begin{tabular}{lllr}
\hline Trichoderma isolates & \multicolumn{3}{l}{ Plant growth characteristics of tomato } \\
\cline { 2 - 4 } & Shoot length (cm) & Stem diameter (mm) & Root length $(\mathbf{c m})$ \\
\hline Control & $19.23^{\mathrm{a}}$ & $0.80^{\mathrm{a}}$ & $8.26^{\mathrm{a}}$ \\
T. harzianum BHU BOT RYRL 4 (NCBI Accession No-KR 856210) & $28.44^{\mathrm{e}}$ & $1.18^{\mathrm{c}}$ & $15.86^{\mathrm{c}}$ \\
T. asperellum BHU BOT RYRL 1 (NCBI Accession No-KR 856207) & $22.22^{\mathrm{ab}}$ & $0.89^{\mathrm{ab}}$ & $10.22^{\mathrm{ab}}$ \\
T. harzianum MTCC 936 & $26.30^{\mathrm{de}}$ & $1.13^{\mathrm{b}}$ & $15.23^{\mathrm{b}}$ \\
T. viride MTCC 793 & $25.40^{\mathrm{cd}}$ & $1.06^{\mathrm{b}}$ & $13.60^{\mathrm{b}}$ \\
T. asperellum MTCC 4347 & $23.34^{\mathrm{bc}}$ & $0.96^{\mathrm{ab}}$ & $11.67^{\mathrm{ab}}$ \\
\hline
\end{tabular}

Values followed by the same letters are not significantly different at $\mathrm{p} \leq 0.05$

length; $136.76 \%$, root length; $184.38 \%$, stem diameter; $141.25 \%$ ) in comparison to control (Table 1). Whereas, T. asperellum BHU BOT RYRL 1 showed the lowest plant growth characteristics (shoot length; 115.54\%, root length; $123.72 \%$, stem diameter; $111.25 \%$ ).

Based on these results, T. harzianum BHU-BOT-RYRL 4 was selected for further experiments.

\section{In vitro antifungal activity of SA and MeJA against Fol and $T$. harzianum}

The mycelial growth of Fol and T. harzianum was not significantly affected by SA and MeJA amendment in PDA medium. Four concentrations of SA and MeJA tested, viz., 50, 100, 150 and $200 \mu \mathrm{M}$, were not found to inhibit mycelial growth of Fol as well as T. harzianum significantly as compared to control. However, beyond $200 \mu \mathrm{M}$, significant reductions in the growth of both the fungi were recorded.

\section{Phytotoxic assay of SA and MeJA against tomato plants}

Four concentrations of SA and MeJA did not show any symptoms of phytotoxicity against tomato plants. Beyond $200 \mu \mathrm{M}$, SA and MeJA showed phytotoxicity against the tomato plants. Hence, the concentration of $200 \mu \mathrm{M}$ for SA and MeJA was selected for spraying on tomato plants.

\section{Total biomass}

Significant increase in growth of tomato plants in terms of dry weight of shoot and root were observed in Fol + SA + Th and Fol + MeJA + Th treated plants in comparison to pathogen challenged plants. But the maximum dry weight of shoot and root by 137.19 and $218.75 \%$ was shown by Fol + SA + Th treated plants. Plants challenged with pathogen had decreased plant root and shoot dry weight when compared with control (Table 2).

\section{Localisation of $\mathrm{H}_{2} \mathrm{O}_{2}$ production}

For the detection of potent sites generating $\mathrm{H}_{2} \mathrm{O}_{2}$ due to the oxidative burst, DAB staining was performed using DAB as a substrate. The principle sites of $\mathrm{H}_{2} \mathrm{O}_{2}$
Table 2 Effect of the pre-treatment of T. harzianum and/ or chemical inducers (SA and MeJA) on the changes in dry weight of shoot and root of tomato plants challenged with Fusarium oxysporum f. sp. lycopersici (Fol)

\begin{tabular}{lll}
\hline Treatments & $\begin{array}{l}\text { Dry weight of shoot (g/ } \\
\text { plant) }\end{array}$ & $\begin{array}{l}\text { Dry weight of root } \\
\text { (g/plant) }\end{array}$ \\
\hline Control & $4.92^{\mathrm{c}}$ & $2.37^{\mathrm{c}}$ \\
Fol & $3.28^{\mathrm{a}}$ & $0.96^{\mathrm{a}}$ \\
$\mathrm{Fol}+$ Th & $4.13^{\mathrm{bc}}$ & $1.61^{\mathrm{ab}}$ \\
$\mathrm{Fol}+\mathrm{SA}$ & $3.91^{\mathrm{ab}}$ & $1.32^{\mathrm{ab}}$ \\
Fol + MeJA & $3.72^{\mathrm{a}}$ & $1.21^{\mathrm{ab}}$ \\
Fol + Th + SA & $4.56^{\mathrm{c}}$ & $2.10^{\mathrm{c}}$ \\
Fol + Th + MeJA & $4.31^{\mathrm{c}}$ & $1.93^{\mathrm{bc}}$
\end{tabular}

Values followed by the same letters are not significantly different at $p \leq 0.05$

generation among the dead cell lesions emerged with having dark brown coloration of polymerized DAB and these sites were found to be more prevalent in pathogen challenged plants followed by those plants which were pretreated with SA along with pathogen. The microscopic observation reveals that the pathogen challenged leaves showed the maximum number of cells undergoing intense dark brown coloration exposing the affected sites for $\mathrm{H}_{2} \mathrm{O}_{2}$ accumulation (Fig. 1d) followed by Fol + SA treated plants (Fig. 1f). Moreover, it was observed that the vascular tissues were also targeted and engaged for generating $\mathrm{H}_{2} \mathrm{O}_{2}$ incited by oxidative burst for those samples which were pretreated with SA along with pathogen. These dark brown coloration precipitates were totally absent from controlled untreated samples (Fig. 1a, b). In comparison between treatments, minimum induction was observed in Fol + MeJA + Th treated plants (Fig. 1g, h).

\section{$\mathrm{H}_{2} \mathrm{O}_{2}$ estimation}

Treatment of tomato leaves with the pathogen, SA, MeJA and $T$. harzianum produced an oxidative burst in the form of $\mathrm{H}_{2} \mathrm{O}_{2}$ production. Treatment with SA especially 

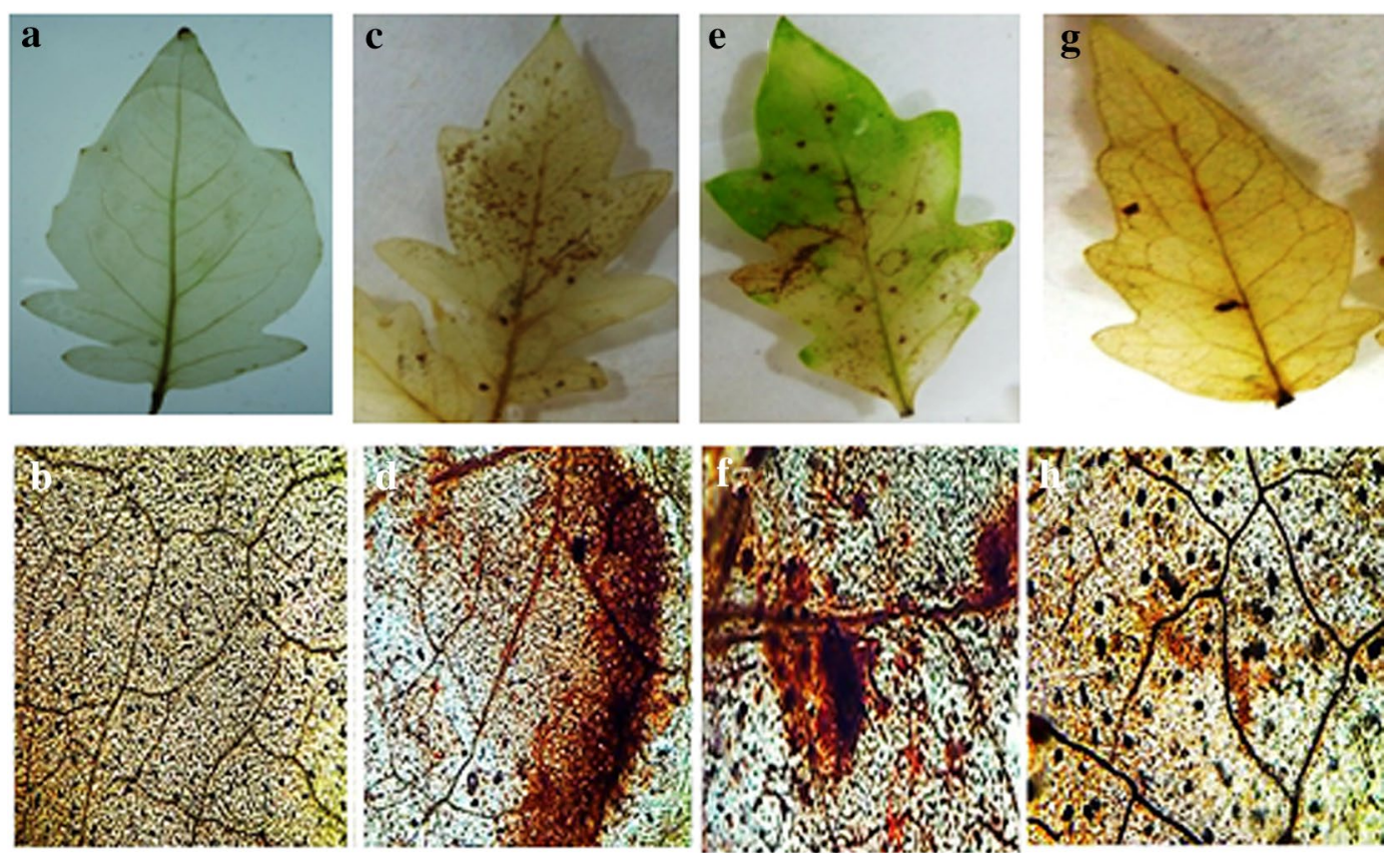

Fig. 1 Localisation of $\mathrm{H}_{2} \mathrm{O}_{2}$ in different treatments of tomato leaves as revealed by reddish brown stain. $\mathbf{a}$, b Unchallenged control (control), c, d challenged with pathogen (Fol). e, f Pre-treated with SA and challenge inoculated with pathogen (Fol + SA). g, h Pre-treated with T. harzianum (Th), MeJA and challenge inoculated with pathogen (Fol + Th + MeJA)

when applied with pathogen markedly increased ROS production. Pathogen stress, SA, MeJA and Th treatment caused a sharp change in $\mathrm{H}_{2} \mathrm{O}_{2}$ content at 24 and $48 \mathrm{~h}$. After $48 \mathrm{~h}$ of treatment, $\mathrm{H}_{2} \mathrm{O}_{2}$ decreased gradually in all treatments. Minimum $\mathrm{H}_{2} \mathrm{O}_{2}$ production was shown by Fol + Th + MeJA treated plants (Fig. 3a).

\section{Measurement of cell death}

Microscopic examination was done after staining the cells with Evans blue dye which clearly reveals the localized region of cell death and extent of damage incited by the oxidative burst. This was easily observed and determined by examining both the treated tissues and control samples under the microscope. The variation in color intensity from light to dark blue clearly pointed out the sites of damaged tissues and the extent of their destruction profile lying in between the live cells. This observed variation in colour intensity is directly proportional to the degree of damages as the fully dead tissues take the intense blue coloration when compared to active tissues from control samples having no coloration. In this study, maximum cell death was shown in pathogen inoculated leaves followed by Fol + SA treated leaves as compared with other treatments (Figs. 2c-f, 3b). Evans blue staining showed that death did not occur in untreated leaf tissue (Fig. 2a, b) while Fol + Th + MeJA treated plants showed minimum cell death (Fig. 2g, h).

\section{Ascorbic acid (AsA) content}

The level of AsA started to rise $24 \mathrm{~h}$ after inoculation reaching an optimal level up to $48 \mathrm{~h}$ and then started to decline after $72 \mathrm{~h}$. The maximum AsA content was more prevalent in leaves treated with Fol $+\mathrm{Th}+\mathrm{SA}$ when compared to single treatments. The total ascorbic acid was found to be highest in Fol $+\mathrm{Th}+\mathrm{SA}$ treated samples whereas the control plants showed no variation in their AsA profile. AsA content was 345.6 and $176.32 \%$ higher in Fol + Th + SA treated plants as compared to control and pathogen challenged plants, respectively (Fig. 4).

\section{Lipid peroxidation}

The Malondialdehyde (MDA) content was significantly higher in pathogen challenged plants and was greatly reduced in the plants pretreated with Th and MeJA together as compared to the other treatments. Levels of MDA slowly increased in leaves of all the treatments but at a particularly lower level in Fol $+\mathrm{Th}+$ MeJA treated tomato plants as compared with the other treatments. The level of MDA gradually increased up to $48 \mathrm{~h}$ after pathogen infection and declined thereafter in all treatments. MDA content was $321.17 \%$ less and $188.36 \%$ higher in the Fol $+\mathrm{Th}+$ MeJA treated plants when compared with pathogen challenged and control plants, respectively. In Fol $+\mathrm{Th}+\mathrm{SA}$ treated plants, it was 132.92\% lesser than pathogen inoculated plants (Fig. 5a). 

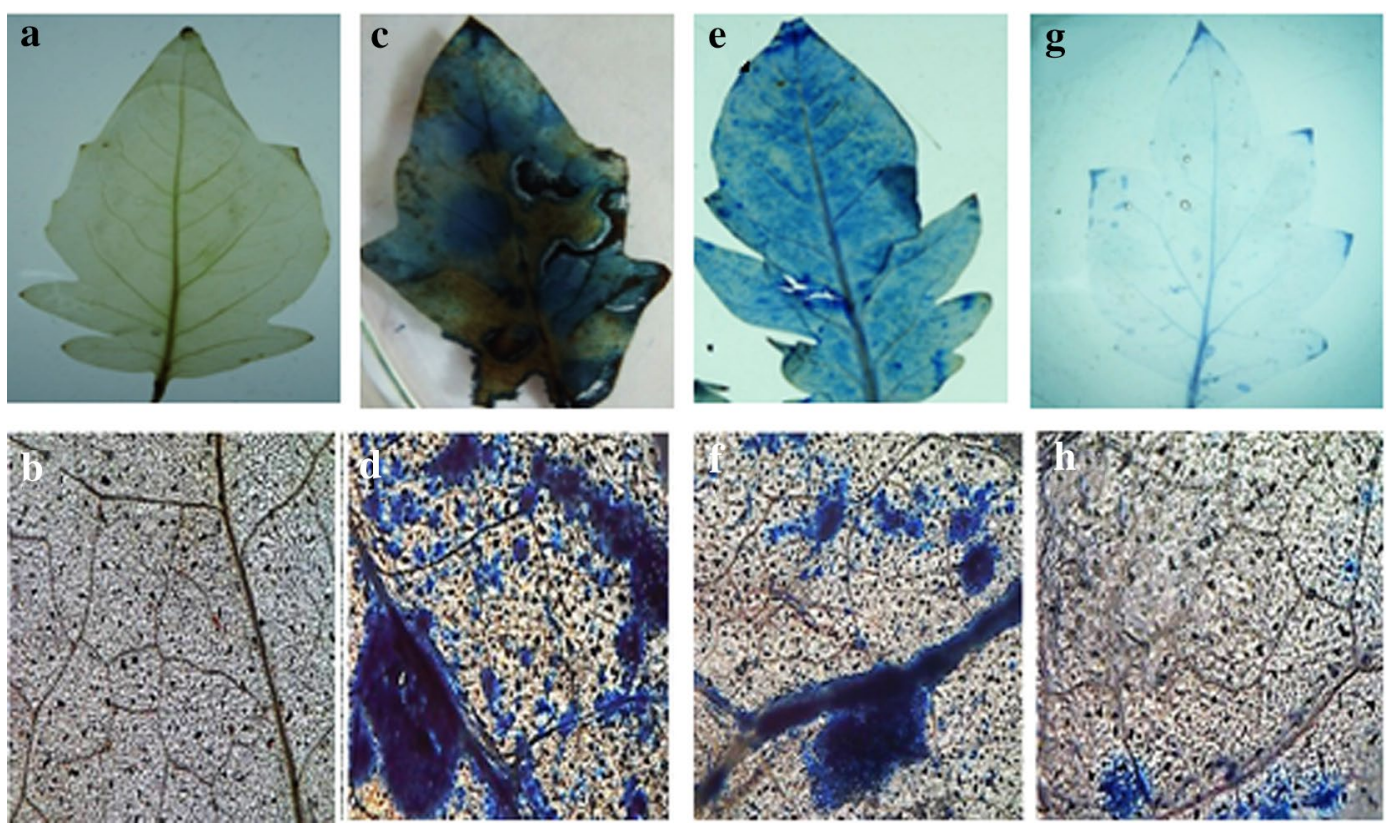

Fig. 2 Localisation of cell death (evans blue uptake) in different treatments of tomato leaves as revealed by blue stain. a, b Unchallenged control (control), c, d challenged with pathogen (Fol). e, f Pre-treated with SA and challenge inoculated with pathogen (Fol + SA). $\mathbf{g}$, h Pre-treated with T. harzianum (Th), MeJA and challenge inoculated with pathogen (Fol + Th + MeJA)
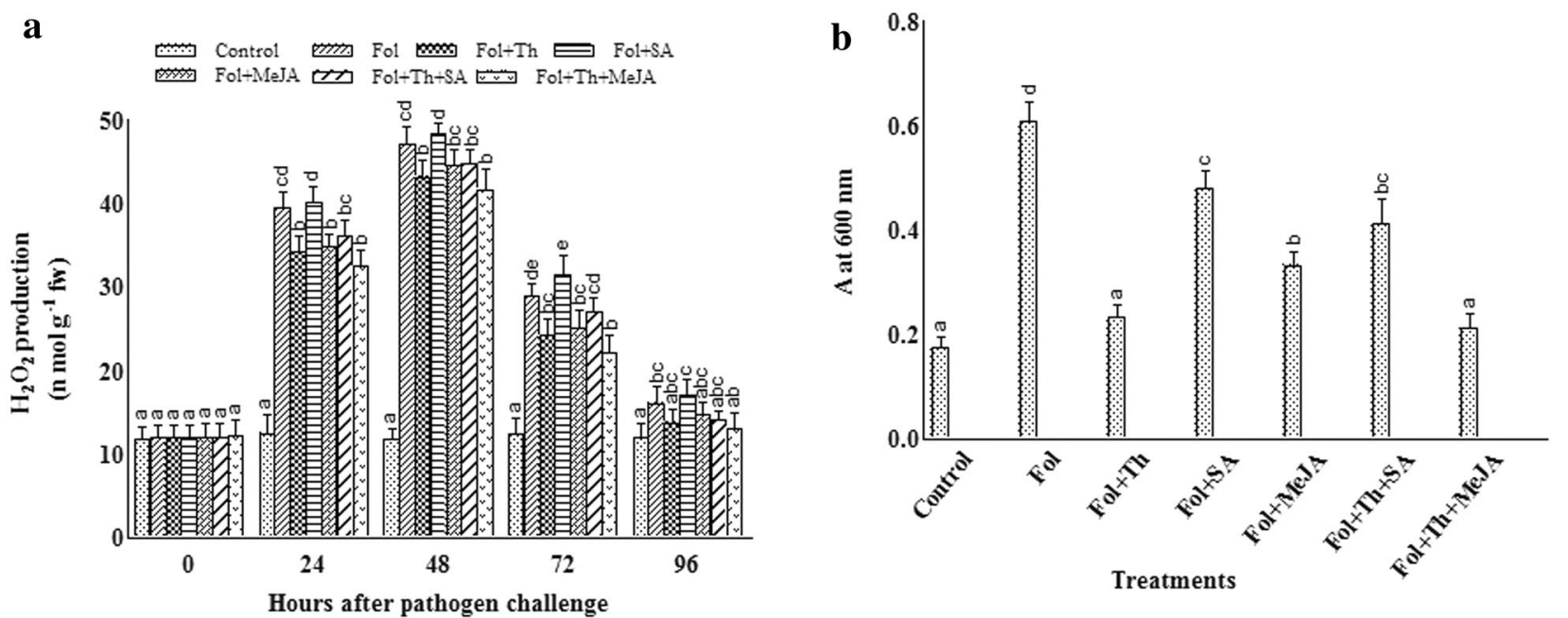

Fig. 3 Estimation of $\mathbf{a} \mathrm{H}_{2} \mathrm{O}_{2}$, and $\mathbf{b}$ cell death in tomato plants pre-treated with T. harzianum, SA and MeJA either individually or in combination after challenge inoculation with Fusarium oxysporum f. sp. Iycopersici (Fol). Results are expressed as the mean of three replicates and vertical bars indicate SD of the mean. Different letters indicate significant differences among treatments within the results taken at the same time interval according to Duncan's multiple range test at $p \leq 0.05$

\section{Antioxidant enzyme activities}

Infection with the pathogen resulted in the general increase in activity of antioxidant enzymes as compared to the control plants. The activities of APx, GPx and CAT increased at $24 \mathrm{~h}$, peaking at $72 \mathrm{~h}$ and decreased slightly thereafter in all applied treatments (Fig. 6a-c).
However, the SOD activity was found maximum at $48 \mathrm{~h}$ and declined thereafter (Fig. 5b). Treatment with chemical inducer especially SA when applied with pathogen markedly decreased $\mathrm{H}_{2} \mathrm{O}_{2}$ scavenging enzymes (APx and CAT) and greatly increased SOD activity in comparison with other treatments. Pre-treatment of tomato 


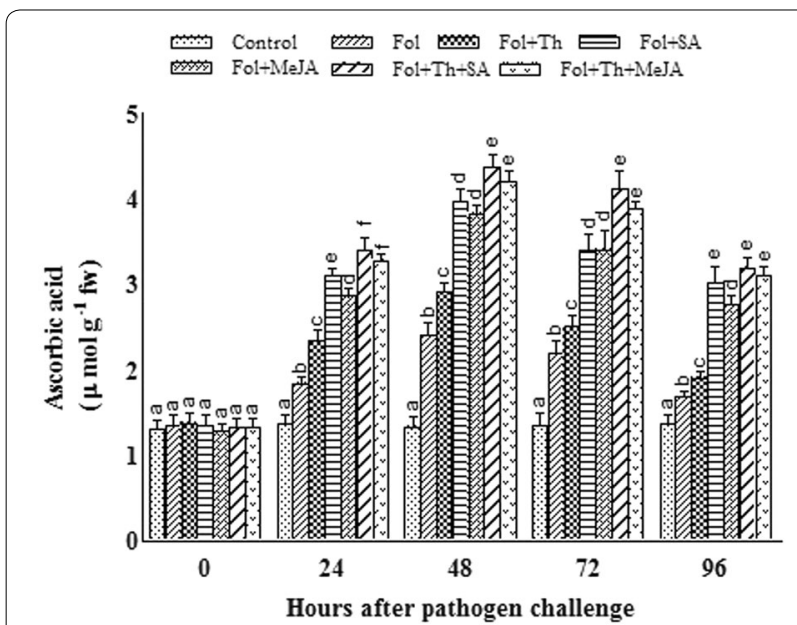

Fig. 4 Estimation of ascorbic acid in tomato plants pre-treated with T. harzianum, SA and MeJA either individually or in combination after challenge inoculation with Fusarium oxysporum f. sp. Iycopersici (Fol). Results are expressed as the mean of three replicates and vertical bars indicate SD of the mean. Different letters indicate significant differences among treatments within the results taken at the same time interval according to Duncan's multiple range test at $p \leq 0.05$

plants with Th and MeJA markedly induced $\mathrm{H}_{2} \mathrm{O}_{2}$ scavenging enzymes and the highest induction was recorded when applied together. The activities of APx and CAT in Fol $+\mathrm{Th}+$ MeJA treated plants were 173.6 and $130.87 \%$ greater than those of the pathogen inoculated plants whereas in the case of Fol $+\mathrm{Th}+\mathrm{SA}$ treated plants, the activities of GPx and SOD were 168.09 and 145.13\% higher than pathogen challenged plants respectively which declined thereafter.

\section{Discussion}

ROS is speculated as the first line of active plant defense against various invading pathogens and may directly act as an antimicrobial agent (Malolepsza and Rozalska 2005; Torres et al. 2006; Shetty et al. 2007). Many reports have shown that $\mathrm{H}_{2} \mathrm{O}_{2}$ is a signaling molecule that plays a significant role in plant defense response (Neuenschwander et al. 1995; Orozco-Cárdenas et al. 2001). ROS generation leads to cellular damage and ultimately cell death. The estimation of cell death and degree of damages due to ROS system can be easily visualized by Evans blue dye whereas the DAB staining predicts the potent sites of $\mathrm{H}_{2} \mathrm{O}_{2}$ generation (Faoro and Iriti 2005). In our study, staining with $\mathrm{DAB}$ and Evans blue, which can visualise $\mathrm{H}_{2} \mathrm{O}_{2}$ accumulation and cell death demonstrates that the pathogen challenged followed by Fol + SA treated plants induced maximum $\mathrm{H}_{2} \mathrm{O}_{2}$ accumulation and cell death in leaf tissues in comparison to other treatments. In the present study, it was evident from the results that there was a more or less steady increase or decrease in the level of the $\mathrm{H}_{2} \mathrm{O}_{2}$ in all the treatments. Maximum $\mathrm{H}_{2} \mathrm{O}_{2}$ production was shown by the plants which were treated with SA along with pathogen or in combination with T. harzianum, while minimum production was shown by the Fol $+\mathrm{Th}+\mathrm{MeJA}$ treated plants. Suppression of $\mathrm{H}_{2} \mathrm{O}_{2}$ production in leaves of Fol + Th + MeJA treatments could be associated with the increased activity of antioxidant enzymes which decreased levels of $\mathrm{H}_{2} \mathrm{O}_{2}$ (either by direct decomposition or oxidation). SA has been shown to increase accumulation of $\mathrm{H}_{2} \mathrm{O}_{2}$ in plants after pathogen infection which activates defense related genes by acting as a secondary messenger (Kauss and
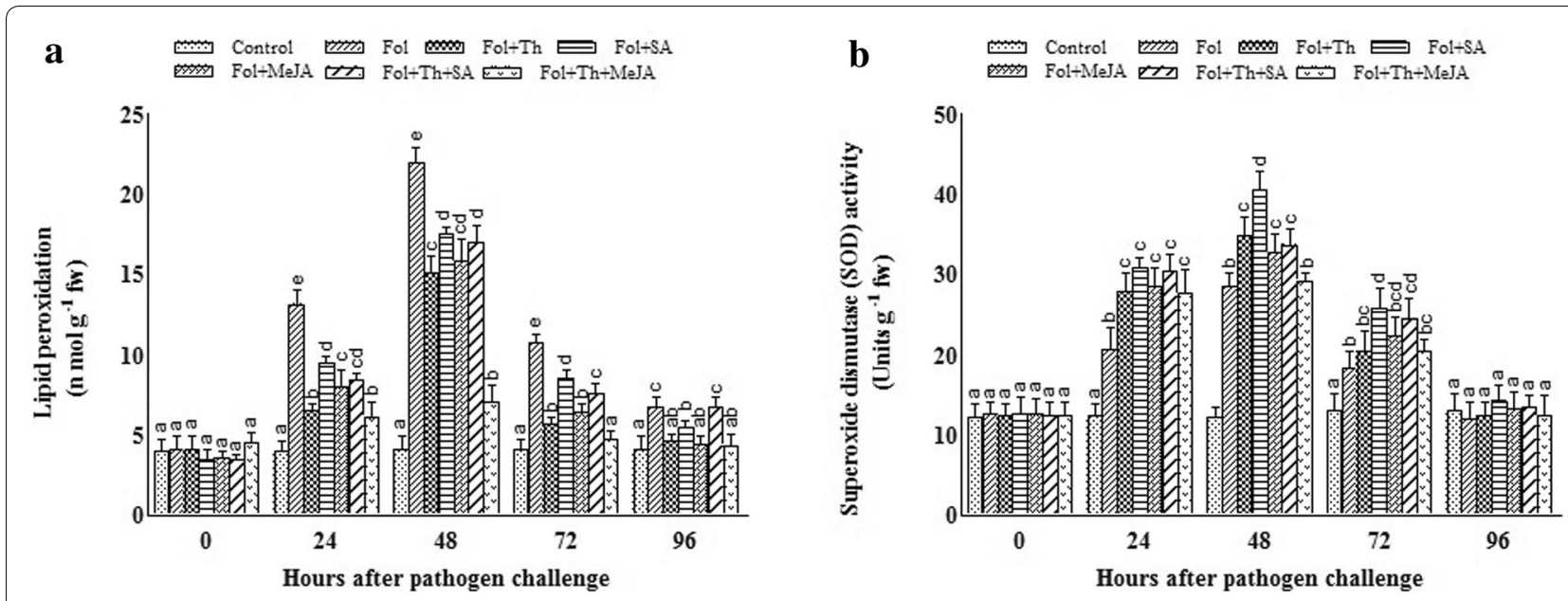

Fig. 5 Estimation of changes in the a concentration of MDA $\mathbf{b}$ activity of SOD, in tomato plants pre-treated with T. harzianum, SA and MeJA either individually or in combination after challenge inoculation with Fusarium oxysporum f. sp. lycopersici (Fol). Results are expressed as the mean of three replicates and vertical bars indicate SD of the mean. Different letters indicate significant differences among treatments within the results taken at the same time interval according to Duncan's multiple range test at $p \leq 0.05$ 

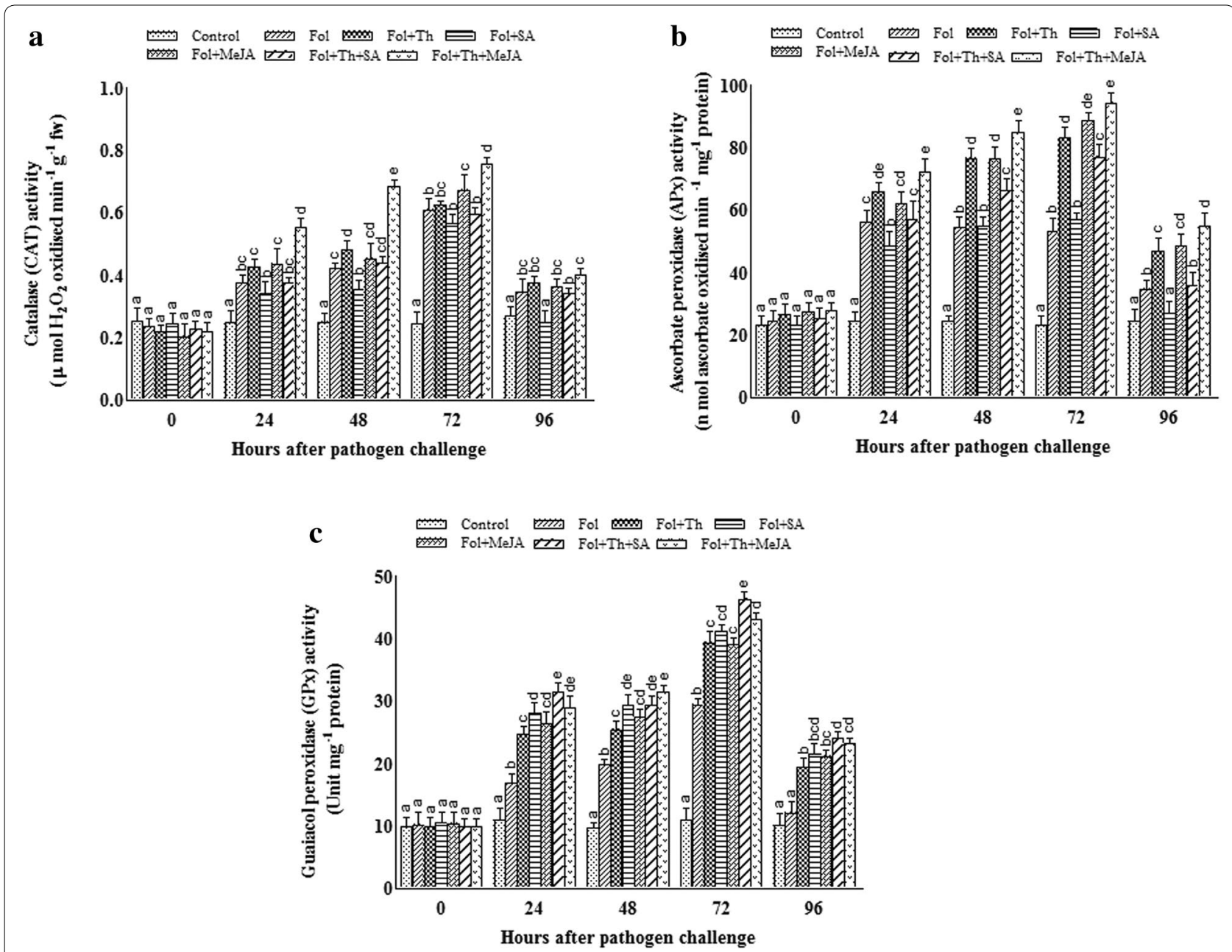

Fig. 6 Estimation of changes in the activities of $\mathbf{a}$ CAT, b APx, and $\mathbf{c ~ G P x ~ i n ~ l e a v e s ~ o f ~ t o m a t o ~ p l a n t s ~ p r e - t r e a t e d ~ w i t h ~ T . ~ h a r z i a n u m , ~ S A ~ a n d ~ M e J A ~}$ either individually or in combination after challenge inoculation with Fusarium oxysporum f. sp. lycopersici (Fol). Results are expressed as the mean of three replicates and vertical bars indicate SD of the mean. Different letters indicate significant differences among treatments within the results taken at the same time interval according to Duncan's multiple range test at $p \leq 0.05$

Jeblick 1996; Garreton et al. 2002; Anand et al. 2008; Lee et al. 2010; Khokon et al. 2011; Miura and Tada 2014). The remarkable role of SA in plants is found to be associated with the activation of many genes whose expression terminates into plant defense activities including generation of $\mathrm{H}_{2} \mathrm{O}_{2}$ and induction of cell death in response to fungal elicitors and wounds (Kauss et al. 1992a, b; Shirasu et al. 1997; Mur et al. 2006). On the contrary, SA is considered to play an important role in preventing the damage to plants against oxidative stress by reducing the accumulation of ROS (Yang et al. 2004). An ambivalent outcome of SA as a prooxidant and antioxidant has been shown in many stress models against various pathogens and several abiotic stresses such as high light intensity, drought, salinity, and cold (Mou et al. 2003; Mateo et al. 2006; Miura and Tada 2014).
The antioxidant enzymes play a defensive role in plants against many oxidative stresses (Saed-Moucheshi et al. 2014). It has been shown that $\mathrm{H}_{2} \mathrm{O}_{2}$ enhances the antioxidant capacity of cells by increasing the activity of various antioxidant enzymes such as CAT, APx and SOD (Xia et al. 2009). The results showed that in the plants infected with F. oxysporum f. sp. lycopersici, the activities of APx, CAT and GPx significantly increased at 48 and $72 \mathrm{~h}$ in comparison to control, but the highest activity of these enzymes were found in plants treated with MeJA and T. harzianum together. However, the plants treated with the chemical inducer SA especially when applied with pathogen, noticeably decreased $\mathrm{H}_{2} \mathrm{O}_{2}$ scavenging enzymes (APx and CAT) and greatly increased SOD activity. The increased SOD activity due to SA might protect biomolecules from being attacked by superoxide radicals 
(Belkadhi et al. 2013). The increased antioxidant enzyme activities in the MeJA and T. harzianum treated plants were more pronounced and higher levels were observed, indicating that the MeJA and Th pretreated plants were highly efficient in scavenging from the deleterious effects of ROS. The SOD enzyme of defense system dismutate the superoxide radicals generated after oxidative metabolism into $\mathrm{H}_{2} \mathrm{O}_{2}$ and $\mathrm{O}_{2}$ which acts as a first line of defense response in plants (Gratão et al. 2012; Radwan 2012). SA plays an important role in generation of $\mathrm{H}_{2} \mathrm{O}_{2}$ (by inhibiting the expression of genes encoding for APx and catalases) which can be correlated with the activation of defense related genes and other enzymes such as SA-insensitive guaiacol peroxidases having an important role in other defense related responses including lignification and crosslinking of cell wall proteins (Gillham and Dodge 1987; Rajan and Murugan 2010). Chen et al. (1993) reported that SA inhibits the catalytic activity of enzyme catalase by binding to it. It has also been proved in tobacco where SA inhibits catalase activity (Conrath et al. 1995). Similarly, the in vitro inhibitory action of SA catalase-inhibiting effect has also been demonstrated in many other plant species such as Arabidopsis, tomato, cucumber (Sanchez-Casas and Klessig 1994), and maize (Horváth et al. 2002).

An initial increase in ascorbic acid content was observed in our study, which was significantly higher in Fol + Th + SA treated plants when compared with pathogen challenged and healthy controls. Thereafter, a marked decline in ascorbic acid content was observed in all treatments. The initial increase in ascorbic acid content in the present study can be explained by the fact that ascorbic acid along with glutathione are present at high concentrations in chloroplast and other cellular organelles which play a promising role in redox buffering of plant cells where they play a key role in plant defense.

The free fatty acids generated after degradation of membrane lipids act as substrate for enzyme lipoxygenase (LOX), causing oxidative deterioration resulting into membrane peroxidation. The membrane peroxidation finally produces various sorts of alkoxy and peroxy radicals including singlet oxygen. These biochemical reactions occurring inside the membrane lead into the major source of ROS generation for plant cells (Farmer and Mueller 2013). In our study, the levels of MDA gradually increased in leaves of infected tomato plants with increasing the time of infection. Tomato plants which were pretreated with Th and chemical inducers (SA and MeJA), MDA levels markedly decreased as compared with pathogen challenged plants. Among these treatments, pathogen challenged plants had the highest MDA level followed by Fol + SA treated plants. The catalytic activity of SOD is associated with the extent of lipid peroxidation as evidenced from the fact that SA treated plants results into the lower degree of membrane damage when compared to plants those were inoculated with the pathogen. One of the critical function of SA involves the activation of SOD that helps in the deactivation of lipid peroxidation thus facilitates in maintaining the integrity of membrane structures of root cells (Zenkov et al. 2001; Belkadhi et al. 2013). Minimum lipid peroxidation was found in Fol + Th + MeJA treated plants. The reduction in lipid peroxidation in tomato plants treated with Th along with MeJA might be related to the enhanced activity of antioxidant enzymes preventing formation and accumulation of free radicals, and subsequently membrane damage.

The individual treatment with chemical inducers like SA or MeJA or Fol elicitors did not have major effect on defense gene expression. However, pre-treatment of plants with these chemical inducers followed by pathogenic inoculation leads into aggravated defense response and characterized by increased expression of defense related genes such as Phenylalanine ammonia lyase $(P A L)$ (in case of SA treatment) or increased expression of $L O X$ genes (MeJA treatment). The two different chemical inducers have different effect on plant defense gene expression in which SA works through systemic acquired resistance (SAR) pathway. The SA in this SAR mediated defense may go through direct activation of PR genes expression or in low doses do not activate defense genes directly but prime the tissue for potentiated defense-gene expression upon subsequent Fol infection. SA-mediated transcriptional responses control the temporal patterns of gene expression in response to stress. Moreover, it has been well demonstrated that SA plays crucial role in Trichoderma root early colonization as revealed through expression studies (Alonso-Ramírez et al. 2014). In contrast, the MeJA as well as Trichoderma inoculated plants mediated defense response through ISR pathways involving ethylene and other hormones. This was confirmed through mutant studies where Trichoderma harzianum was inoculated with wild type as well mutants affected in the biosynthesis of specific defenserelated hormones were selected, including the JA-deficient defenseless1 (def1), the SA-deficient NahG, the ABA-deficient sitiens and the ET-under producing ACC deaminase $A C D$ (Martínez-Medina et al. 2013). In all cases the mutant plants were found to be susceptible for disease development even after Trichoderma inoculation, indicating that JA-regulated pathway is required for TISR against pathogen challenged conditions. Recently, Rubio et al. (2017) have evaluated the defense gene expression following the combined treatment of Trichoderma harzianum T34 with NPK supplemented and under salt stressed conditions and demonstrated the expression 
of expression of eight genes out of nine analyzed: EIN2, encoding a central component of the ET signaling pathway; NPR1, which encodes a key transducer of SA signaling involved in plant defense responses; $A R E B 2$, encoding a transcription factor (TF) of $A B A$ signaling; $L E R B O H 1$, involved in ROS production; $A P X 1$, encoding an ascorbate peroxidase; $S O S 1$, which encodes a salt tolerance marker; $A R F 1$, encoding a TF that binds to auxin response elements; and DREB3, a marker gene involved in tolerance to drought. AsA is a very important antioxidant, which protects the plants under oxidative stress (Shafiq et al. 2014). It has been reported that exogenous application of JA increases AsA in different plants suggesting that JA may regulate AsA metabolism (AyalaZavala et al. 2010; Chen and Gu 2014).

Trichoderma induced systemic resistance (TISR) in tomato against Fol challenged conditions is mainly based on boosted JA-dependent responses, the pathways regulated by the plant hormones-SA is also required for successful TISR development (Martínez-Medina et al. 2013). Priming for enhanced resistance to biotic and abiotic stress obviously is operating via various pathways involved in different metabolic processes. This suggests that the mode of action of priming and the resulting potentiation of cellular defense responses rather than the direct upregulation of defense signaling cascades might be of great advantage for living organisms. Plants pretreated with bioagent and chemical inducers together become primed to respond faster and show stronger activation of cellular defense responses after pathogen challenge compared with control plants. Higher induction of antioxidant enzymes in the plants which are pretreated with biological and chemical inducers in the present study can be correlated as a defense response triggered against $F$. oxysporum f. sp. lycopersici invasion in tomato plants.

\section{Conclusion}

The present study showed that the pre-treatment of the tomato plants with chemical inducers SA, MeJA and biocontrol agent $T$. harzianum induced the defense system against $F$. oxysporum f. sp. lycopersici infection with the increased expression of various antioxidant enzymes leading to enhanced defense response. In conclusion, it can be said that combinations of biocontrol agent and chemical inducers can be a useful and better promising measures for suppressing Fusarium wilt disease more efficiently than using alone due to the involvement of a number of defense mechanisms.

\section{Abbreviations}

Fol: Fusarium oxysporum f. sp. lycopersici; Th: Trichoderma harzianum; SA: salicylic acid; MeJA: methyl jasmonate; MDA: malondialdehyde; CAT: catalase;
SOD: superoxide dismutase; APx: ascorbate peroxidase; GPx: guaiacol peroxidase; $\mathrm{ROS}$ : reactive oxygen species; $\mathrm{H}_{2} \mathrm{O}_{2}$ : hydrogen peroxide; SAR: systemic acquired resistance; ISR: induced systemic resistance.

\section{Authors' contributions}

AZ sample collected, executed most of the experiments and designed the manuscript. MM, MKD and MA executed some of the experiments, RSU Resolution of the critical questions related to the accuracy of the data. All authors read and approved the final manuscript.

\section{Author details \\ ${ }^{1}$ Laboratory of Mycopathology and Microbial Technology, Centre of Advanced Study in Botany, Banaras Hindu University, Varanasi, Uttar Pradesh 221 005, India. ${ }^{2}$ Department of Botany, Banaras Hindu University, Varanasi 221 005 , India.}

\section{Acknowledgements}

Financial support for this work by the University Grants Commission, (UGC), Government of India is gratefully acknowledged.

\section{Competing interest}

The authors declare that they have no competing interests.

\section{Publisher's Note}

Springer Nature remains neutral with regard to jurisdictional claims in published maps and institutional affiliations.

Received: 27 April 2016 Accepted: 20 October 2017

Published online: 02 November 2017

\section{References}

Aebi H (1984) Catalase in vitro. Methods Enzymol 105:12-16

Alfano G, Ivey MLL, Cakir C, Bos JIB, Miller SA, Madden LV, Kamoun S, Hoitink HAJ (2007) Systemic modulation of gene expression in tomato by Trichoderma hamatum 382. Phytopathology 97:429-437

Alonso-Ramírez A, Poveda J, Martín I, Hermosa R, Monte E, Nicolás C (2014) Salicylic acid prevents Trichoderma harzianum from entering the vascular system of roots. Mol Plant Pathol 15(8):823-831

Anand A, Uppalapati SR, Ryu CM, Allen SN, Kang L, Tang Y, Mysore KS (2008) Salicylic acid and systemic acquired resistance play a role in attenuating crown gall disease caused by Agrobacterium tumefaciens. Plant Physiol 146:703-715

Ayala-Zavala J, Rosas-Domínguez C, Vega-Vega V, González-Aguilar G (2010) Antioxidant enrichment and antimicrobial protection of fresh-cut fruits using their own byproducts: looking for integral exploitation. J Food Sci 75(8):R175-R181

Baker CJ, Mock NM (1994) An improved method for monitoring cell death in cell suspension and leaf disc assays using evans blue. Plant Cell Tissue Organ Cult 39:7-12

Baxter A, Mittler R, Suzuki N (2013) ROS as key players in plant stress signalling. J Exp Bot. https://doi.org/10.1093/jxb/ert375

Belkadhi A, De Haro A, Soengas P, Obregon S, Cartea ME, Djebali W, Chaïbi W (2013) Salicylic acid improves root antioxidant defense system and total antioxidant capacities of flax subjected to cadmium. OMICS J Integr Biol 17:398-406

Bokhari NA, Perveen K (2012) Antagonistic action of Trichoderma harzianum and Trichoderma viride against Fusarium solani causing root rot of tomato. Afr J Microbiol Res 6:7193-7197

Brotman Y, Lisec J, Meret M, Chet I, Willmitzer L, Viterbo A (2012) Transcript and metabolite analysis of the Trichoderma-induced systemic resistance response to Pseudomonas syringae in Arabidopsis thaliana. Microbiology 158:139-146

Chen H, Gu Z (2014) Effect of ascorbic acid on the properties of ammonia caramel colorant additives and acrylamide formation. J Food Sci 79:C1678-C1682

Chen Z, Silva H, Klessig RF (1993) Active oxygen species in the induction of plant systemic acquired resistance by SA. Science 262:1883-1886 
Conrath U, Chen ZX, Ricigliano JR, Klessig DF (1995) Two inducers of plant defense responses, 2,6-dichloroisonicotinec acid and salicylic acid, inhibit catalase activity in tobacco. Proc Natl Acad Sci USA 92:7143-7147

Creelman RA, Mullet JE (1995) Jasmonic acid distribution and action in plants: regulation during development and response to biotic and abiotic stress. Proc Natl Acad Sci USA 92:4114-4119

Creissen G, Edwards A, Mullineaux P (1994) Glutathione reductase and ascorbate peroxidase. In: Foyer $\mathrm{CH}$, Mullineaux PM (eds) Causes of photooxidative stress and amelioration of defense system in plants. CRC Press, Boca Raton, pp 343-364

Delaney TP, Uknes S, Vernooij B, Friedrich L, Weymann K, Negrotto D, Gaffney T, Gut-Rella M, Kessmann H, Ward E et al (1994) A central role of salicylic acid in plant disease resistance. Science 266:1247-1249

Edreva A (2004) A novel strategy for plant protection: induced resistance. J Cell Mol Biol 3:61-69

El-Khallal SM (2007a) Induction and modulation of resistance in tomato plants against Fusarium wilt disease by bioagent fungi (arbuscular mycorrhiza) and/or hormonal elicitors (jasmonic acid \& salicylic acid): 1-changes in growth, some metabolic activities and endogenous hormones related to defence mechanism. Aust J Basic Appl Sci 1:691-705

El-Khallal SM (2007b) Induction and modulation of resistance in tomato plants against Fusarium wilt disease by bioagent fungi (arbuscular mycorrhiza) and/or hormonal elicitors (jasmonic acid \& salicylic acid): 2-changes in the antioxidant enzymes, phenolic compounds and pathogen relatedproteins. Aust J Basic Appl Sci 1:717-732

Faoro F, Iriti M (2005) Cell death behind invisible symptoms: early diagnosis of ozone injury. Biol Plant 49:585-592

Farmer EE, Mueller MJ (2013) ROS-mediated lipid peroxidation and RES-activated signaling. Annu Rev Plant Biol 64:429-450

Fridovich I (1974) Superoxide dismutases. Adv Enzymol Relat Areas Mol Biol 41:35-97

Garreton V, Carpinelli J, Jordana X, Holuigue L (2002) The as-1 promoter element is an oxidative stress-responsive element and salicylic acid activates it via oxidative species. Plant Physiol 130:1516-1526

Garrett SD (1956) Biology of root-infecting fungi. Cambridge University Press, New York, p 293

Gillham DJ, Dodge AD (1987) Chloroplast superoxide and hydrogen peroxide scavenging systems from pea leaves: seasonal variation. Plant Sci 50:105-109

Gratão PL, Monteiro CC, Carvalho RF, Tezotto T, Piotto FA, Peres LEP, Azevedo RA (2012) Biochemical dissection of diageotropica and never ripe tomato mutants to Cd-stressful conditions. Plant Physiol Biochem 56:79-96

Hahlbrock K, Scheel D (1989) Physiology and molecular biology of phenylpropanoid metabolism. Annu Rev Plant Physiol Plant Mol Biol 40:347-369

Hanaa RMF, Abdou ZA, Salama DA, Ibrahim MAR, Sror HAM (2011) Effect of neem and willow aqueous extracts on fusarium wilt disease in tomato seedlings: induction of antioxidant defensive enzymes. Ann Agric Sci $56: 1-7$

Harman GE, Howell CR, Viterbo A, Chet I, Lorito M (2004) Trichoderma speciesopportunistic, avirulent plant symbionts. Nat Rev Microbiol 2:43-56

Hermosa R, Viterbo A, Chet I, Monte E (2012) Plant-beneficial effects of Trichoderma and of its genes. Microbiology 158:17-25

Herrera-Vásquez A, Salinas P, Holuigue L (2015) Salicylic acid and reactive oxygen species interplay in the transcriptional control of defense genes expression. Front Plant Sci 6:171

Horváth E, Janda T, Szalai G, Páldi E (2002) In vitro salicylic acid inhibition of catalase activity in maize: differences between the isoenzymes and a possible role in the induction of chilling tolerance. Plant Sci 163:1129-1135

Idress M, Naeem N, Aftab T, Khan MMA (2011) Salicylic acid mitigates salinity stress by improving antioxidant defense system and enhances vincristine and vinblastine alkaloids production in periwrinkle (Catharanthus roseus (L.) G. Don). Acta Physiol Plant 33:987-999

Kang G, Li G, Guo T (2014) Molecular mechanism of salicylic acid-induced abiotic stress tolerance in higher plants. Acta Physiol Plant 36:2287-2297

Kapsiya J, Gungula DT, Tame VT, Bukar N (2015) Effects of storage chemicals and packaging systems on physicochemical characteristics of tomato (Solanum lycopersicum L.) fruits. AASCIT J Biosci 1:41-46

Kauss H, JeblickW (1996) Influence of salicylic acid on the induction of competence for $\mathrm{H}_{2} \mathrm{O}_{2}$ elicitation. Plant Physiol 11:755-763
Kauss H, Krause K, JeblickW (1992a) Methyl jasmonate conditions parsley suspension cells for increased elicitation of phenylpropanoid defense responses. Biochem Biophys Res Commun 189:304-308

Kauss H, Theisinger-Hinkel E, Mindermann R, Conrath U (1992b) Dichloroisonicotinic and salicylic acid, inducers of systemic acquired resistance, enhance fungal elicitor responses in parsley cells. Plant J 2:655-660

Keller T, Schwager H (1977) Air pollution and ascorbic acid. Eur J For Pathol 7:338-350

Khokon AR, Okuma E, Hossain MA, Munemasa S, Uraji M, Nakamura Y et al (2011) Involvement of extracellular oxidative burst in salicylic acid induced stomatal closure in Arabidopsis. Plant Cell Environ 34:434-443

Kozlowski G, Buchala A, Metraux JP (1999) Methyl jasmonate protects Norway spruce [Picea abies (L.) Karst.] seedlings against Pythium ultimum Trow. Physiol Mol Plant Pathol 55:53-58

Lee S, Kim SG, Park CM (2010) Salicylic acid promotes seed germination under high salinity by modulating antioxidant activity in Arabidopsis. New Phytol 188:626-637

Lehmann S, Serrano M, L'Haridon F, Tjamos SE, Metraux JP (2015) Reactive oxygen species and plant resistance to fungal pathogens. Phytochemistry 112:54-62

Lowry OH, Rosebrough NJ, Farr AL, Randall RJ (1951) Protein measurement with the Folin phenol reagent. J Biol Chem 193:265-275

Malolepsza U, Rozalska S (2005) Nitric oxide and hydrogen peroxide in tomato resistance, nitric oxide modulates hydrogen peroxide level in o-hydroxyethylorutin-induced resistance to Botrytis cinerea in tomato. Plant Physiol Biochem 43:623-635

Marra R, Ambrosino P, Carbone V, Vinale F, Woo SL, Ruocco M, Ciliento R, Lanzuise S, Ferraioli S, Soriente I, Gigante S, Turra D, Fogliano V, Scala F, Lorito M (2006) Study of the three-way interaction between Trichoderma atroviride, plant and fungal pathogens by using a proteomic approach. Curr Genet 50:307-321

Martínez-Medina A, Fernández I, Sánchez-Guzmán MJ, Jung SC, Pascual JA, Pozo MJ (2013) Deciphering the hormonal signalling network behind the systemic resistance induced by Trichoderma harzianum in tomato. Front Plant Sci 4:206

Mateo A, Funck D, Mühlenbock P, Kular B, Mullineaux PM, Karpinski S (2006) Controlled levels of salicylic acid are required for optimal photosynthesis and redox homeostasis. J Exp Bot 57:1795-1807

Maurhofer M, Hase C, Meuwly P, Metraux JP, Defago G (1994) Induction of systemic resistance of tobacco to tobacco necrosis virus by the rootcolonizing Pseudomonas fluorescens strain CHAO: influence of the gacA gene and of pyoverdine production. Phytopathology 84:139-146

Mittler R, Vanderauwera S, Suzuki N, Miller G, Tognetti VB, Vandepoele K, Gollery M, Shulaev V, Van Breusegem F (2011) ROS signaling: the new wave? Trends Plant Sci 16:300-309

Miura K, Tada Y (2014) Regulation of water, salinity, and cold stress responses by salicylic acid. Front Plant Sci 5:4

Mou Z, Fan W, Dong X (2003) Inducers of plant systemic acquired resistance regulate NPR1 function through redox changes. Cell 113:935-944

Mur LA, Kenton P, Atzorn R, Miersch O, Wasternack C (2006) The outcomes of concentration-specific interactions between salicylate and jasmonate signaling include synergy, antagonism, and oxidative stress leading to cell death. Plant Physiol 140:249-262

Nakano Y, Asada K (1981) Hydrogen peroxide is scavenged by ascorbate-specific peroxidase in spinach chloroplasts. Plant Cell Physiol 22:867-880

Neuenschwander U, Vernooij B, Fridrich L, Uknes S, Kessmann H, Ryals J (1995) Is hydrogen peroxide a second messenger of salicylic acid in systemic acquired resistance? Plant J 8:227-233

Ohkawa H, Ohishi N, Yagi K (1979) Assay for lipid peroxides in animal tissues by thiobarbituric acid reaction. Anal Biochem 95:351-358

Orozco-Cárdenas ML, Narváez-Vásquez J, Ryan CA (2001) Hydrogen peroxide acts as a second messenger for the induction of defense genes in tomato plants in response to wounding, systemin, and methyl jasmonate. Plant Cell 13:179-191

Park KS, Kloepper JW (2000) Activation of PR-1 a promoter by rhizobacteria that induce systemic resistance in tobacco against Pseudomonas syringae pv. tabaci. Biol Control 18:2-9

Radwan DEM (2012) Salicylic acid induced alleviation of oxidative stress caused by clethodim in maize (Zea mays L.) leaves. Pest Biochem Physiol 102:182-188 
Rajan SS, Murugan K (2010) Purification and kinetic characterization of the liverwort Pallavicinia lyelli (Hook.) S. Gray. cytosolic ascorbate peroxidase. Plant Physiol Biochem 48:758-763

Ramamoorthy V, Viswanathan R, Raguchandar J, Prakasham T, Samiyappan R (2001) Induction of systemic resistance by plant growth promoting rhizobacteria in crop plants against pest and diseases. Crop Prot 20:1-11

Rubio MB, Hermosa R, Vicente R, Gómez-Acosta FA, Morcuende R, Monte E, Bettiol W (2017) The combination of Trichoderma harzianum and chemical fertilization leads to the deregulation of phytohormone networking, preventing the adaptive responses of tomato plants to salt stress. Front Plant Sci. https://doi.org/10.3389/fpls.2017.00294

Saed-Moucheshi A, Pakniyat H, Pirasteh-Anosheh H, Azooz MM (2014) Role of ROS as signaling molecules in plants. Elsevier Inc, Amsterdam

Sagisaka S (1976) The occurrence of peroxide in a perennial plant, Populus gelrica. Plant Physiol 57:308-309

Sanchez-Casas P, Klessig DF (1994) A salicylic acid-binding activity and a salicylic acid-inhibitable catalase activity are present in a variety of plant species. Plant Physiol 106:1675-1679

Scandalios JG, Guan L, Polidoros AN (1997) Catalases in plants: gene structure, properties, regulation, and expression. In: Scandalios JG (ed) Oxidative stress and the molecular biology of antioxidant defenses. Cold Spring Harbor Laboratory Press, Cold Spring Harbor, pp 343-406

Segarra G, Casanova E, Bellido D, Odena MA, Oliveira E, Trillas I (2007) Proteome, salicylic acid and jasmonic acid changes in cucumber plants inoculated with Trichoderma asperellum strain T34. Proteomics 7:3943-3952

Shafiq S, Akram NA, Ashraf M, Arshad A (2014) Synergistic effects of drought and ascorbic acid on growth, mineral nutrients and oxidative defense system in canola (Brassica napus L.) plants. Acta Physiol Plant 36:1539-1553

Shetty NP, Mehrabi R, Lutken H, Haldrup A, Kema GH, Collenge DP, Jorgenson HJ (2007) Role of hydrogen peroxide during the interaction between the hemibiotrophic fungal pathogen Septoria tritici and wheat. New Phytol 174:637

Shimizu N, Hosogi N, Hyon G-S, Jiang S, Inoue K, Park P (2006) Reactive oxygen species (ROS) generation and ROS-induced lipid peroxidation are associated with plasma membrane modifications in host cells in response to AK-toxin I from Alternaria alternata Japanese pear pathotype. J Gen Plant Pathol 72:6-15
Shirasu K, Nakajima H, Rajasekhar VK, Dixon RA, Lamb C (1997) Salicylic acid potentiates an agonist-dependent gain control that amplifies pathogen signals in the activation of defence mechanisms. Plant Cell 9:261-270

Shoresh M, Harman GE, Mastouri F (2010) Induced systemic resistance and plant responses to fungal biocontrol agents. Annu Rev Phytopathol 48:21-43

Sticher L, Mauch-Mani B, Metraux JP (1997) Systemic acquired resistance. Annu Rev Phytopathol 35:235-270

Thordal-Christensen H, Zhang Z, Wei Y, Collinge DB (1997) Subcellular localization of $\mathrm{H}_{2} \mathrm{O}_{2}$ in plants. $\mathrm{H}_{2} \mathrm{O}_{2}$ accumulation in papillae and hypersensitive response during the barley - powdery mildew interaction. Plant J 11:1187-1194

Torres MA, Jonathan DG, Dangl JL (2006) Reactive oxygen species signaling in response to pathogen. Plant Physiol 141:373-378

Vinale F, Sivasithamparam K, Ghisalberti EL, Marra R, Woo SL, Lorito M (2008) Trichoderma - plant-pathogen interactions. Soil Biol Biochem 40:1-10

War AR, Paulraj MG, War MY, Ignacimuthu S (2011a) Role of salicylic acid in induction of plant defense system in chickpea (Cicer arietinum L.). Plant Signal Behav 6:1787-1792

War AR, Paulraj MG, War MY, Ignacimuthu S (2011b) Jasmonic acid-mediated induced resistance in groundnut (Arachis hypogaea L.) against Helicoverpa armigera (Hubner) (Lepidoptera: Noctuidae). J Plant Growth Regul 30:512-523

Xia XJ, Wang YJ, Zhou YH, Tao Y, Mao WH, Shi K, Asami T, Chen Z, Yu JQ (2009) Reactive oxygen species are involved in brassinosteroid-induced stress tolerance in cucumber. Plant Physiol 150:801-814

Yang YN, Qi M, Mei CS (2004) Endogenous salicylic acid protects rice plants from oxidative damage caused by aging as well as biotic and abiotic stress. Plant J 40:909-919

Zenkov NK, Lankin VE, Menshchikova EV (2001) Okislitel'nyi stress (oxidative stress). Nauka, Moscow, p 280

Zheng X, Van Huystee RB (1992) Peroxidase-regulated elongation of segments from peanut hypocotyls. Plant Sci 81:47-56

\section{Submit your manuscript to a SpringerOpen ${ }^{\circ}$ journal and benefit from:}

- Convenient online submission

- Rigorous peer review

- Open access: articles freely available online

- High visibility within the field

- Retaining the copyright to your article

Submit your next manuscript at $\boldsymbol{\nabla}$ springeropen.com 